\title{
Impact of agglomeration state of nano- and submicron sized gold particles on pulmonary inflammation
}

Ilse Gosens ${ }^{1 *}$, Jan Andries Post ${ }^{2}$, Liset JJ de la Fonteyne ${ }^{3}$, Eugene HJM Jansen ${ }^{3}$, John W Geus ${ }^{2}$, Flemming R Cassee ${ }^{1}$, Wim H de Jong $^{3}$

\begin{abstract}
Background: Nanoparticle (NP) toxicity testing comes with many challenges. Characterization of the test substance is of crucial importance and in the case of NPs, agglomeration/aggregation state in physiological media needs to be considered. In this study, we have addressed the effect of agglomerated versus single particle suspensions of nano- and submicron sized gold on the inflammatory response in the lung. Rats were exposed to a single dose of $1.6 \mathrm{mg} / \mathrm{kg}$ body weight (bw) of spherical gold particles with geometric diameters of $50 \mathrm{~nm}$ or $250 \mathrm{~nm}$ diluted either by ultrapure water or by adding phosphate buffered saline (PBS). A single dose of $1.6 \mathrm{mg} / \mathrm{kg}$ bw DQ12 quartz was used as a positive control for pulmonary inflammation. Extensive characterization of the particle suspensions has been performed by determining the zetapotential, $\mathrm{pH}$, gold concentration and particle size distribution. Primary particle size and particle purity has been verified using transmission electron microscopy (TEM) techniques. Pulmonary inflammation (total cell number, differential cell count and pro-inflammatory cytokines), cell damage (total protein and albumin) and cytotoxicity (alkaline phosphatase and lactate dehydrogenase) were determined in bronchoalveolar lavage fluid (BALF) and acute systemic effects in blood (total cell number, differential cell counts, fibrinogen and C-reactive protein) 3 and 24 hours post exposure. Uptake of gold particles in alveolar macrophages has been determined by TEM.

Results: Particles diluted in ultrapure water are well dispersed, while agglomerates are formed when diluting in PBS. The particle size of the $50 \mathrm{~nm}$ particles was confirmed, while the $250 \mathrm{~nm}$ particles appear to be $200 \mathrm{~nm}$ using tracking analysis and $210 \mathrm{~nm}$ using TEM. No major differences in pulmonary and systemic toxicity markers were observed after instillation of agglomerated versus single gold particles of different sizes. Both agglomerated as well as single nanoparticles were taken up by macrophages.

Conclusion: Primary particle size, gold concentration and particle purity are important features to check, since these characteristics may deviate from the manufacturer's description. Suspensions of well dispersed $50 \mathrm{~nm}$ and $250 \mathrm{~nm}$ particles as well as their agglomerates produced very mild pulmonary inflammation at the same mass based dose. We conclude that single $50 \mathrm{~nm}$ gold particles do not pose a greater acute hazard than their agglomerates or slightly larger gold particles when using pulmonary inflammation as a marker for toxicity.
\end{abstract}

\section{Background}

The small size and subsequent relative increase in surface area-to-volume ratios of nanoparticles (NPs) results in special and desired properties for which NPs are engineered. It is hypothesized that this also contributes

\footnotetext{
* Correspondence: ilse.gosens@rivm.nl

${ }^{1}$ Centre for Environmental Health Research, National Institute for Public

Health and the Environment, Bilthoven, the Netherlands

Full list of author information is available at the end of the article
}

to making nanoparticles chemically more reactive leading to unexpected and aberrant effects upon interaction with biological systems compared to sub-micron sized particles of the same material. In a number of studies, the toxicity of nanoparticles (NPs) has been related to their small size and therefore high surface area per unit mass as well as proportionally having more atoms on the surface available for chemical reactions [1-7].

\section{Biomed Central}


When performing a toxicity study, characterization of the test substance is of crucial importance in order to understand the parameters that can be used to predict the hazard of NPs. Primary particle size, shape, surface area, surface chemistry, surface charge, solubility or dissolution rate, purity and agglomeration state can all influence NPs toxicity [8]. In this study, the focus is on agglomeration state of particles of two different sizes and how this can influence the biological response after administration into the lung. Agglomeration of particles is a basic process that results in a reduction of surface free energy by increasing their size and decreasing their surface area. Agglomeration of nanoparticles is due to adhesion of particles to each other by weak forces leading to (sub)micronsized entities. In contrast, nanoparticle aggregates are due to the formation of covalent or metallic bonds that cannot be easily disrupted. Both agglomeration and aggregation raise questions how to address the evaluation of safety of NPs when they are no longer in the nano range, but are present as larger entities [9]. It is not known whether agglomerated particles could become single particles again when introduced in a biological system, while several studies have shown that single particles have the ability to form agglomerates in a biological matrix $[10,11]$. From a toxicological perspective, it is important to determine how the human body deals with single nanoparticles compared to agglomerates. In the workplace, inhalation of engineered nanoparticles is a realistic exposure scenario during production and handling [12]. Nanoparticles can exist in the form of single (primary) particles as well as agglomerates or aggregates.

Also the primary size of a particle (nano- versus submicron sized) could result in a different biological response. It is currently thought that single nanoparticles could (also) pose a greater hazard compared to larger particles due to their ability to translocate across barriers $[13,14]$ and possibly to by-pass the pulmonary immune system e.g. by less efficient macrophage uptake [15]. The impact of agglomeration state of particles on these effects is not extensively studied.

Colloidal gold particles of $50 \mathrm{~nm}$ and $250 \mathrm{~nm}$ with a citrate coating are chosen as model particles to study effects on pulmonary endpoints, since they can be synthesized with a narrow size distribution as stable suspensions. Toxic effects of gold nanoparticles have been observed in vitro. For example, 14-nm colloidal gold particles were found to cross the cell membrane of dermal fibroblasts in culture and accumulate into vacuoles. The presence of the particles is responsible for abnormal actin filaments and extracellular matrix constructs, thereby inducing adverse effects on cell viability [16]. Conflicting results have been obtained regarding the cytotoxicity of gold, ranging from non-cytotoxic for
$15 \mathrm{~nm}$ particles and $3.5+/-0.7 \mathrm{~nm}$ particles capped with lysine and poly-L-lysine [17] and to cytotoxic for 1.2 and $1.4 \mathrm{~nm}$ particles [18]. Gold $2 \mathrm{~nm}$ nanoparticles functionalized with cationic groups were moderately toxic in contrast to particles with anionic groups that were not toxic [19]. Gold particles have also been used to determine the fate as a function of size after different exposure routes. To what extent the agglomeration state will influence this, is largely unknown. In most studies, particles have been administered in an agglomerated state or as a mix of single and agglomerated particles via intravenous injection, intratracheal instillation and inhalation. After inhalation of nanogold particles (with a primary size of 5-8 $\mathrm{nm}$ and present in the aerosol as agglomerates of $30-110 \mathrm{~nm}$ or at least smaller than 100 $\mathrm{nm}$, respectively), small quantities of particles translocate from the lung to other organs [20,21]. After intravenous injection [22] and intratracheal instillation $[23,24]$, nano-sized particles have the ability to reach more distal regions of the body compared to their larger counterparts.

In this study we determine to what extend the agglomeration state of $50 \mathrm{~nm}$ and $250 \mathrm{~nm}$ particles influences pulmonary effects in the rat. A single dose of $1.6 \mathrm{mg} / \mathrm{kg}$ body weight of spherical gold particles of either $50 \mathrm{~nm}$ or $250 \mathrm{~nm}$ is intratracheally instilled in the rat lung after diluting either by $1 / 10$ volume of ultrapure water to obtain single particles or by $1 / 10$ volume of $10 \times$ phosphate buffered saline (PBS) to obtain agglomerates. This method of delivery was chosen over the physiological route of exposure via inhalation based on the possibility to administer particle solutions containing single particles versus agglomerates, more exact dosing, reduction of costs as well as less complexity in exposure of the animals. Intratracheal instillation is a widely accepted alternative for delivery of particles to the lung $[25,26]$.

\section{Results}

\section{Characterization of particles}

The $50 \mathrm{~nm}$ and $250 \mathrm{~nm}$ gold particles were custom prepared at a concentration of $2 \mathrm{mg} / \mathrm{ml}$ and have a citrate shell for stabilization. Diluting the $50 \mathrm{~nm}$ particle solution using ultrapure water did not result in a colour change and particle size distribution measurements using the Nanosight apparatus indicated a highest peak size (size distribution peak with most particles) and mean particle size of around $50 \mathrm{~nm}$ (table 1), indicating that the citrate shell remains stabilized. Diluting the $50 \mathrm{~nm}$ particles using 1 part $10 \times$ PBS and 9 parts $50 \mathrm{~nm}$ particle suspension to obtain a physiological solution resulted in a colour change from red to blue with the highest peak and mean particle size above $100 \mathrm{~nm}$ indicating the formation of agglomerates [22]. 
Table 1 Particle size distribution and zetapotential

\begin{tabular}{lccc}
\hline & highest peak size \pm sd & mean size \pm sd & zetapotential $(\mathbf{m V}) \pm \mathbf{s d}$ \\
\hline $50 \mathrm{~nm}$ gold single & $54 \pm 3$ & $61 \pm 3$ & $-56 \pm 0,42$ \\
\hline $50 \mathrm{~nm}$ gold agg & $114 \pm 73$ & $199 \pm 88$ & $-54 \pm 1,01$ \\
\hline $250 \mathrm{~nm}$ gold single & $197.5 \pm 7$ & $197 \pm 12$ & $-53 \pm 0,53$ \\
\hline $250 \mathrm{~nm}$ gold agg & $762 \pm 762$ & $768 \pm 766$ & $-61 \pm 0,98$ \\
\hline
\end{tabular}

Highest peak size and mean particle size in this distribution is determined by tracking analysis of Brownian motion. Zetapotential is determined by using the Zetasizer instrument.

The $50 \mathrm{~nm}$ particles in this dilution remained in suspension for approximately 5 minutes. Then particles started to precipitate at the bottom of the tube with a clearer aqueous solution on top. The resulting cluster of gold particles could no longer be homogenized by sonication. This effect was not observed for any other particle dilution that has been prepared. Therefore, $50 \mathrm{~nm}$ particles were mixed with PBS immediately before instillation and particle size distribution was measured directly afterwards to avoid this phenomenon. The highest peak size and mean particle size of $250 \mathrm{~nm}$ particles in ultrapure water were similar as indicated by a single distribution peak determined in the Nanosight apparatus. Dilution by using $10 \times$ PBS resulted in larger agglomerates with a large size distribution (table 1).

All solutions were electrically stabilized based on zetapotentials (between -40 and $-60 \mathrm{mV}$ ) for single particles solutions as well as agglomerates (table 1). The $\mathrm{pH}$ measurement of the $50 \mathrm{~nm}$ and $250 \mathrm{~nm}$ gold particle solutions as well as the control solution indicated that they are in the physiological range of $\mathrm{pH}$ 6.4-7.0.

According to the supplier, the concentration of the gold particles suspensions should be $2 \mathrm{mg} / \mathrm{ml}$. ICP-MS measurements revealed a lower concentration of $0.9 \pm$ $0.02 \mathrm{mg} / \mathrm{ml}$ for $50 \mathrm{~nm}$ particles and $1.1 \pm 0.02 \mathrm{mg} / \mathrm{ml}$ for $250 \mathrm{~nm}$ particles. The administered dose was $405 \mu \mathrm{g} / \mathrm{rat}$ equivalent to $1.6 \mathrm{mg} / \mathrm{kg}$ body weight (bw).

Using the Nanosight apparatus (table 1) as well as TEM (figure $1 \mathrm{~A}$ and $1 \mathrm{~B}$ ), the particle size of the $50 \mathrm{~nm}$ particles was confirmed at $50 \mathrm{~nm}$, while the $250 \mathrm{~nm}$

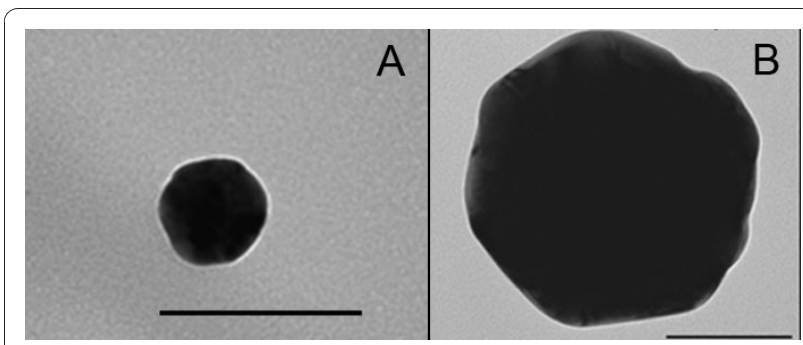

Figure 1 TEM of single $\mathbf{5 0}$ and $\mathbf{2 5 0} \mathbf{n m}$ particles. A) Primary particle size of $50 \mathrm{~nm}$ gold particles was confirmed. B) The average primary particle size $250 \mathrm{~nm}$ gold particle was assessed at $210 \mathrm{~nm}$. Bars represent $100 \mathrm{~nm}$. particles appeared to be smaller, namely $200 \mathrm{~nm}$ by tracking analysis versus $210 \mathrm{~nm}$ by TEM.

The gold particles of $50 \mathrm{~nm}$ appeared to be monocrystalline; the diffraction maxima and the lattice images pointed to pure $\mathrm{Au}$ (data not shown). Some gold particles of $250 \mathrm{~nm}$ consisted of two or three smaller not intimately connected particles. An example is shown in figure $2 \mathrm{~A}$. These composite $250 \mathrm{~nm}$ particles do not exhibit a monocrystalline diffraction pattern and a spherical or facetted shape as the $50 \mathrm{~nm}$ particles (data not shown). figure $2 \mathrm{~B}$ represents three gold particles of about $250 \mathrm{~nm}$. The secondary electron image demonstrated the individual particles to be well facetted, while other gold particles were fractured and had thus no symmetrical shape (figure $2 \mathrm{C}$ ). The high-angle annular dark field (HAADF) images of both the 50 and the $250 \mathrm{~nm}$ particles showed the presence of areas containing carbon and oxygen on which some silicon containing areas were present, most likely in the form of $\mathrm{SiO}_{2}$ (data not shown). The carbon and oxygen may be due to the presence of citrates.

\section{Biological response}

Three and 24 hours after instillation, several parameters were determined in the BALF. Single $250 \mathrm{~nm}$ particles induced a significant increase in the percentage of neutrophils after 24 hours (table 2). The percentage differential cell counts 24 hours after instillation showed that there is a shift towards a neutrophil influx at the expense of the percentage of macrophages compared to

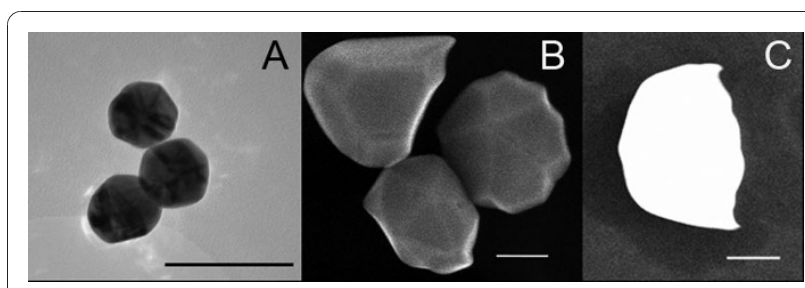

Figure 2 TEM of $250 \mathrm{~nm}$ particles. A) Some $250 \mathrm{~nm}$ gold particles consisted of multiple smaller units of about $50 \mathrm{~nm}$. B) Secondary electron image of well faceted and grouped $250 \mathrm{~nm}$ particles. C) Example of a fractured $250 \mathrm{~nm}$ gold particle, secondary electron image. Bars represent $100 \mathrm{~nm}$. 
Table 2 Cell, macrophage and neutrophil concentration in BALF

\begin{tabular}{|c|c|c|c|c|c|c|}
\hline \multirow[b]{2}{*}{ Treatment } & \multicolumn{2}{|c|}{ Total cell $(10 \mathrm{E} 6 / \mathrm{ml})$} & \multicolumn{2}{|c|}{ Macrophage 10E6/ml) } & \multicolumn{2}{|c|}{ Neutrophil $(10 \mathrm{E} 5 / \mathrm{ml})$} \\
\hline & $3 \mathrm{hrs}$ & $24 \mathrm{hrs}$ & $3 \mathrm{hrs}$ & $24 \mathrm{hrs}$ & $3 \mathrm{hrs}$ & $24 \mathrm{hrs}$ \\
\hline - control & $0.29 \pm 0.05$ & $0.72 \pm 0.17$ & $0.23 \pm 0.06$ & $0.61 \pm 0.14$ & $0.09 \pm 0.02$ & $0.57 \pm 0.44$ \\
\hline 50 single & $0.29 \pm 0.04$ & $0.71 \pm 0.20$ & $0.22 \pm 0.04$ & $0.55 \pm 0.19$ & $0.14 \pm 0.07$ & $0.99 \pm 0.49$ \\
\hline 250 single & $0.30 \pm 0.11$ & $0.74 \pm 0.19$ & $0.26 \pm 0.11$ & $0.49 \pm 0.13$ & $0.22 \pm 0.16$ & $1.5 \pm 0.84^{*}$ \\
\hline 50 agg & $0.30 \pm 0.10$ & $0.54 \pm 0.23$ & $0.25 \pm 0.10$ & $0.39 \pm 0.20$ & $0.17 \pm 0.13$ & $1.0 \pm 0.59$ \\
\hline 250 agg & $0.36 \pm 0.08$ & $1.02 \pm 0.45$ & $0.30 \pm 0.06$ & $0.84 \pm 0.42$ & $0.19 \pm 0.18$ & $1.0 \pm 0.76$ \\
\hline quartz & $0.54 \pm 0.31^{*}$ & $2.16 \pm 0.62^{*}$ & $0.47 \pm 0.28^{*}$ & $0.32 \pm 0.15$ & $0.27 \pm 0.14$ & $17.2 \pm 7.6^{*}$ \\
\hline
\end{tabular}

Average concentration $\pm s d$. Statistical significant differences $P<0.05$ are indicated by *

the negative control (figure 3), except for $250 \mathrm{~nm}$ agglomerates where the percentage in differential cell count did not change, albeit a trend towards an increase in total number of cells and absolute number of macrophages has been observed (table 2). This neutrophil influx was minor after gold particle treatment and much larger after quartz that is used as a reference material for inflammation (table 2 and figure 3). After quartz instillation, there was a significant increase in total cell numbers as well as macrophages after 3 hours and neutrophils after 24 hours. In addition, an increase in MIP-2 (figure 4A) and a tendency to an increase in MCP-1 levels (data not shown) was found, as expected [27]. TNF- $\alpha$ and IL-6 levels were around the detection limit. After instillation of $250 \mathrm{~nm}$ single gold particles, a trend towards an increase was found for IL-6 (figure 4B) and TNF- $\alpha$ levels (figure 4C). Agglomerated $50 \mathrm{~nm}$ particles resulted in increased levels of TNF- $\alpha$ after 3 hours, albeit not significant (figure 4C).

Analysis of damage markers total protein and albumin revealed no significant differences in the BALF after gold instillation (data not shown). The agglomerated 50 $\mathrm{nm}$ particles induced an increase in ALP (alkaline phosphatase) activity after 3 hours (figure $5 \mathrm{~A}$ ). Increased ALP activity in BALF has been associated with type II epithelial cell damage [28]. Quartz at $1.6 \mathrm{mg} / \mathrm{kg}$ bw

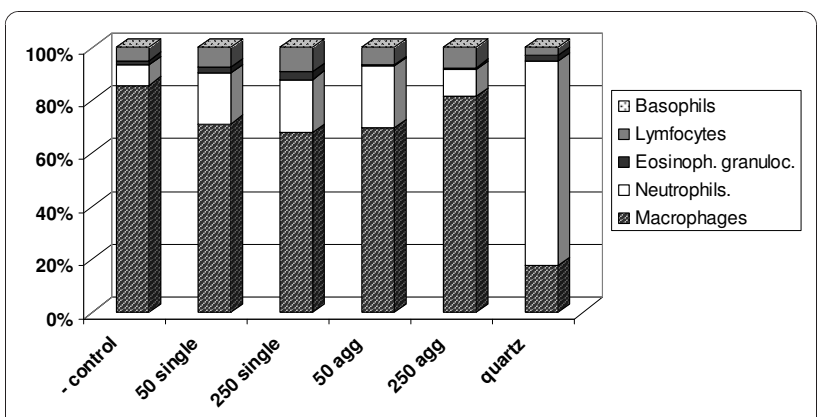

Figure 3 Differential cell counts in BALF. The percentage macrophages, neutrophils, eosinophilic granulocytes, lymphocytes and basophils were given per treatment group 24 hours after instillation ( $n=6$ for gold and $n=3$ for quartz). resulted in cellular damage as can be seen by an increase in ALP (figure 5A) and lactate dehydrogenase (LDH) (figure 5B) after 24 hours.

Light microscopic analysis revealed dark coloured material inside macrophages of animals that were dosed with $50 \mathrm{~nm}$ and $250 \mathrm{~nm}$ particles, either agglomerated or as single particles. In control animals that did not receive any particles, no material was seen (Additional file 1, Figure S1). For both sizes of particles, $60-80$ out of 100 macrophages contained this material. Transmission electron microscopy images showed that $50 \mathrm{~nm}$ and $250 \mathrm{~nm}$ particles were taken up by alveolar macrophages when the particles were administered either as single particles (figure 6A, 6B, 6C, 6D), as $50 \mathrm{~nm}$ agglomerated particles (figure $6 \mathrm{~F}$ and $6 \mathrm{G}$ ) or as $250 \mathrm{~nm}$ particles (figure $6 \mathrm{H}$ and $6 \mathrm{I}$ ). Analysis of elements in HAADF mode confirmed that it were indeed gold particles (figure 6E).

No significant differences in vWF and IL-6 levels in citrate plasma were found (data not shown). Single $250 \mathrm{~nm}$ and agglomerated $50 \mathrm{~nm}$ gold particles increased fibrinogen levels after 24 hours (figure 7A). After gold and quartz instillations CRP levels were elevated compared to the negative control after 3 hours (figure 7B). Upregulation of these acute phase proteins indicate a general response to tissue injury.

\section{Discussion}

Size differences as well as the agglomeration state of citrate stabilized gold particles of $50 \mathrm{~nm}$ and $250 \mathrm{~nm}$ have been determined and the impact on the biological response in the lung has been established in this study. Size is one of the important characteristics for the deposition pattern and fate of particles in the body. Particle size affects the accessibility of target organs, the mode of cellular uptake, endocytosis and efficiency of particle processing in the endocytic pathway. Here, we show that $50 \mathrm{~nm}$ gold particles that were administered as a well dispersed single particle suspension or as an agglomerated suspension are taken up by macrophages. The particles end up in the cytoplasm inside vesicles and not in other structures. This has also been observed 


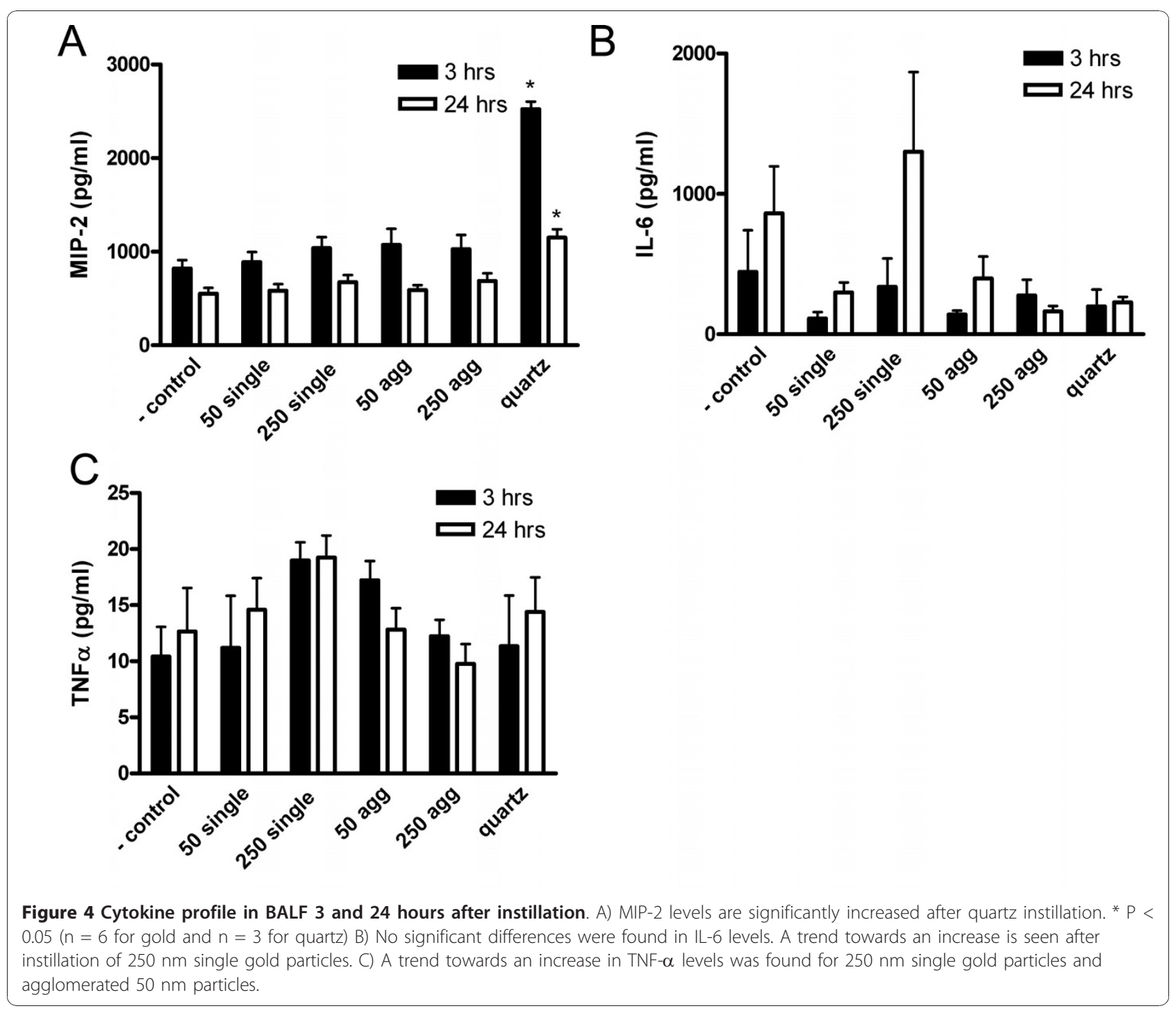

in another study in vivo study for agglomerated 5-8 nm gold particles [21]. In all cases, nanoparticles were surrounded by a membrane (figure 6), indicating that the uptake of the nanoparticles occurred by endo- or phagocytosis. Certain vesicular structures contain a single NP of $50 \mathrm{~nm}$, whereas others contain more than just one. There is evidence for macrophage phagocytic function to be size dependent [5]. Alveolar macrophages phagocytise spherical particles of 1-2 $\mu \mathrm{m}$ most effectively and uptake has been seen up to $5 \mu \mathrm{m}$ [29]. In vitro, particles of $300 \mathrm{~nm}$ are less well phagocytised compared to $5 \mu \mathrm{m}$ [30]. Particle uptake in macrophages for nano-sized $\mathrm{TiO}_{2}$ has been estimated to be between 0.06 and $0.12 \%$ within 24 hours compared to micron sized particles. For the latter, $10 \%$ uptake is seen within the first hour [31] and more than $80 \%$ within 24 hours [15]. The set-up of this study did not allow quantification of the uptake. Although under the light microscope, the number of macrophages that were filled with material seemed comparable, it was more difficult to visualize macrophages containing $250 \mathrm{~nm}$ particles after 24 hours than $50 \mathrm{~nm}$ particles in TEM evaluation. This has also been seen before in our unpublished pilot study where we could visualize $250 \mathrm{~nm}$ particles in only a few macrophages.

The overall findings on biological parameters after gold instillation based on the pulmonary and blood markers are summarized in table 3. MIP-2 and MCP-1 were only affected by quartz and are therefore not mentioned in the table. TNF- $\alpha$ and IL- 6 levels after quartz instillation were around detection levels as determined in two independent experiments using ELISA kits from different manufacturers. In literature, controversial results have been described with respect to increased TNF- $\alpha$ and IL-6 levels after quartz exposure. While some in vivo studies do show a significant increase [32], other studies only show an increase in vitro and not in vivo 

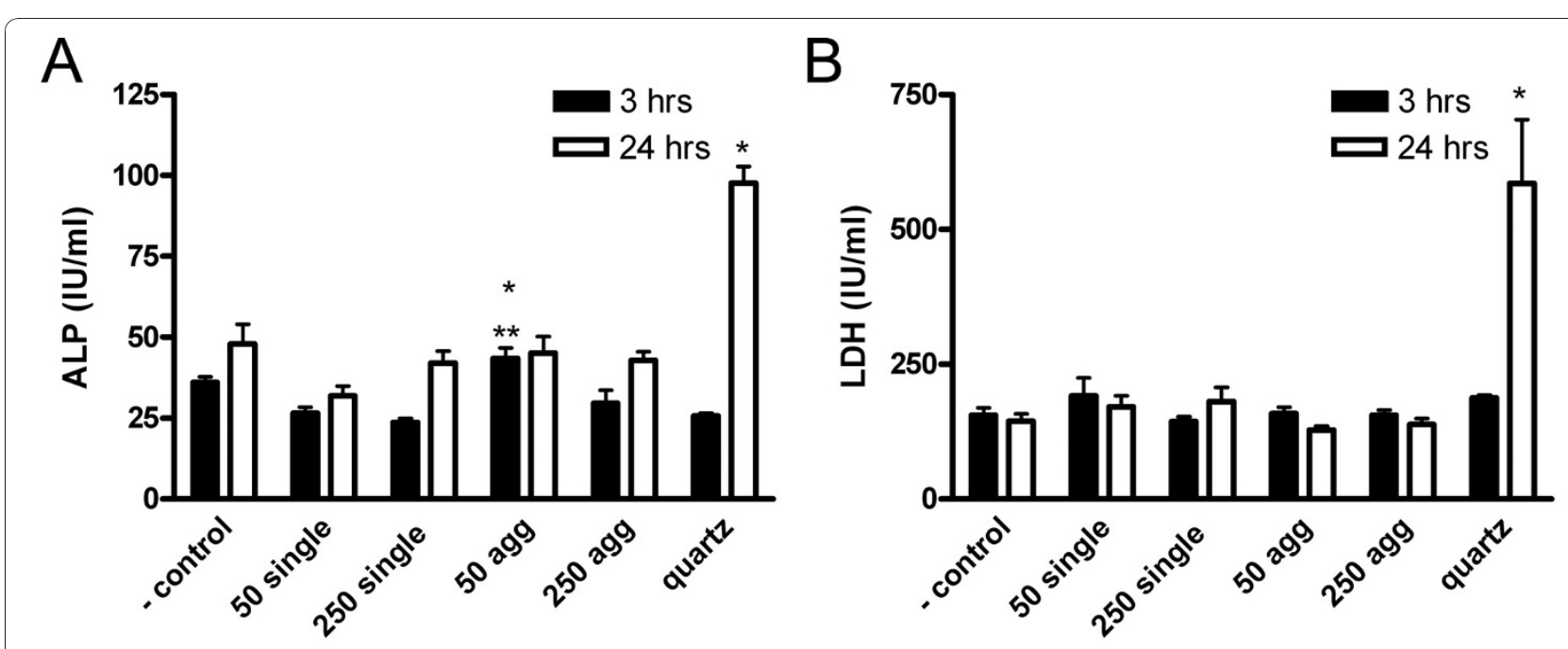

Figure 5 Cell damage markers in BALF 3 and $\mathbf{2 4}$ hours after instillation. A) Alkaline phosphatase (ALP) levels are significantly increased 3 hours after $50 \mathrm{~nm}$ gold agglomerates and 24 hours after quartz instillation. ${ }^{*} \mathrm{P}<0.05$ compared to negative control, ${ }^{*} \mathrm{P}<0.05$ compared to $50 \mathrm{~nm}$ single gold particles. B) LDH levels are significantly increased 24 hours after quartz instillation ( $n=6$ for gold and $n=3$ for quartz).

$[33,34]$. A NF $\kappa$ B inflammatory mechanism for DQ12 quartz that is partly TNF- $\alpha$ independent has been postulated [34].

When comparing $50 \mathrm{~nm}$ single versus $50 \mathrm{~nm}$ agglomerated particles, most changes on biological variables were found after instillation of agglomerated nanoparticles: a significant increase in ALP, fibrinogen and CRP is accompanied by a trend towards a neutrophil influx and an increase in TNF- $\alpha$ levels. Single $50 \mathrm{~nm}$ particles induced an increase in CRP levels and there was a trend towards an increase in neutrophils. Single $250 \mathrm{~nm}$ particles increased the number of neutrophils and the levels of fibrinogen and CRP. The response was accompanied by a trend towards an increase in TNF- $\alpha$ and IL-6. Agglomerated $250 \mathrm{~nm}$ particles only induced a significant increase in CRP. Moreover a (statistically not significant) increase in total cell number and the number of macrophages was noted. TNF- $\alpha$ is mainly produced by macrophages and stimulates phagocytosis. It also acts together with IL-6 (trend towards increase) by promoting inflammation by attracting neutrophils [35]. After increases in circulating TNF- $\alpha$, the liver is stimulated to produce acute phase proteins like $\mathrm{C}$-reactive protein (CRP) and fibrinogen. Most effects were found for single $250 \mathrm{~nm}$ particles, since all these parameters were affected. The $250 \mathrm{~nm}$ agglomerates, $50 \mathrm{~nm}$ agglomerates (that are the same mean size as the primary $250 \mathrm{~nm}$ particles) or $50 \mathrm{~nm}$ single particles did not affect these parameters to the same extent (table 1).

The hypothesis that single nanoparticles could be more toxic than larger counterparts either formed by agglomeration or larger primary size particles does not apply to the gold particles that were administered here in a single dose of $1.6 \mathrm{mg} / \mathrm{kg}$ bw to the lung. The least effects in this study were seen after administration of single $50 \mathrm{~nm}$ particles. At least two reasons have been hypothesized to explain why NPs could be more toxic: 1 . there are more reactive atoms on the surface and more surface per unit mass. 2. nanoparticles that are small enough could exert quantum effects due to constraint chemical bonds that are more likely to be disrupted [36]. A recent systematic literature overview by Auffan et al. suggested that inorganic metal and metal oxide nanoparticles with a primary particle size below 20-30 nm are likely to show different chemical properties not seen in bulk material [37]. In the case of gold, catalytic activity has been observed for particles of smaller than $10 \mathrm{~nm}[38,39]$. The nanoparticles of $50 \mathrm{~nm}$ used in this study are not likely to induce increased biological responses due to enhanced chemical reactivity compared to the submicron sized gold particles.

When suspended in PBS instead of ultrapure water, our study showed a 2-4 times increase in overall particle size. Particle agglomerate and aggregate formation in physiological media such as PBS has been observed for a number of different types of particles smaller than 100 $\mathrm{nm}$ resulting in entities that were 3-6 times larger [11]. These effects are influenced by $\mathrm{pH}$, ionic strength, and different types of ions in aqueous suspensions [40]. Agglomerates are held together by weak forces such as van der Waals forces, electrostatic interactions or surface tension. After 5 minutes, $50 \mathrm{~nm}$ particles assembled to form large precipitates that could not be brought back into suspension using e.g. sonication. The gold 

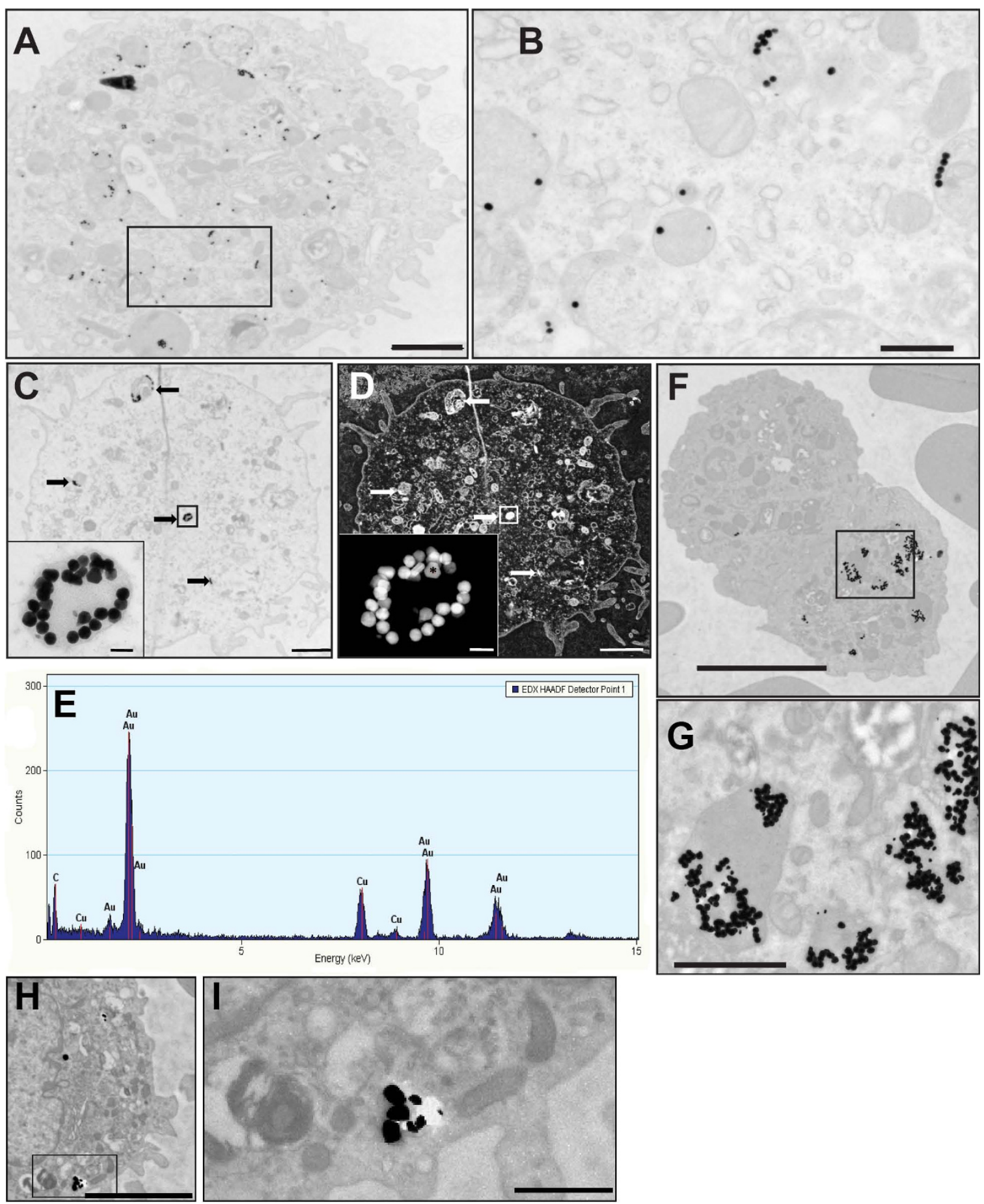

Figure 6 TEM of macrophages in BALF 24 hours after instillation. Uptake of $50 \mathrm{~nm}$ gold particles. Panels A-E concern instillation of gold particles in ultrapure water, panels $F$ and G concern gold particles in PBS. A) Alveolar macrophage with multiple organelles containing $50 \mathrm{~nm}$ gold particles that were instilled as a well dispersed suspension containing single particles. B) Enlargement of the square in A, shows the presence of cellular structures containing one or more nanoparticles. C) Accumulation of agglomerates of nano-particles within organelles (arrows); the insert represents the vesicular structure containing over 25 nanoparticles in the black square. D) Same macrophage as shown in C now in HAADF mode. E) An EDX HAADF analysis has been performed on the nanoparticle indicated with an * in the insert and the presence of gold (Au) is confirmed. F) Agglomerated $50 \mathrm{~nm}$ gold particles were observed in the macrophages, although heterogeneity in cellular uptake is observed. G) Enlargement of the square in F. H) $250 \mathrm{~nm}$ gold particles were also found in the macrophages with an enlargement of the square in I). The bars represent: A, C, D: $2 \mu \mathrm{m}, \mathrm{B}: 500 \mathrm{~nm}$, inserts C/D: $100 \mathrm{~nm}, \mathrm{~F}$ and H: $5 \mu \mathrm{m}, \mathrm{G}$ and I: $1 \mu \mathrm{m}$. 

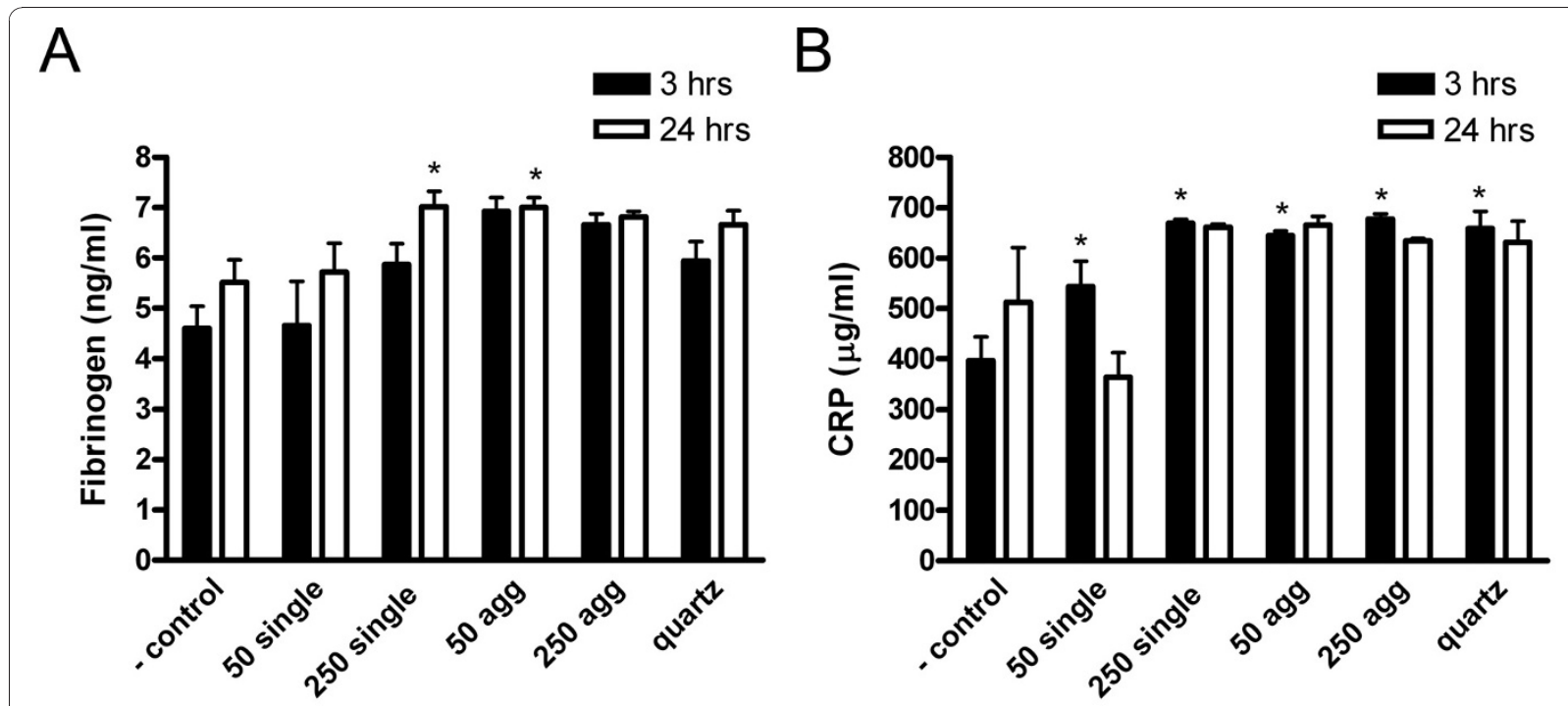

Figure $\mathbf{7}$ Acute phase protein in serum $\mathbf{3}$ and $\mathbf{2 4}$ hours after instillation. A) Fibrinogen levels are significantly increased after $250 \mathrm{~nm}$ single and $50 \mathrm{~nm}$ agglomerated particles. B) CRP levels are significantly increased 3 hours after gold and quartz treatment. ${ }^{*} \mathrm{P}<0.05$ compared to negative control ( $n=6$ for gold and $n=3$ for quartz).

nanoparticles have a negative surface charge as a result of the weakly bound citrate coating [41]. Gold colloids are vulnerable to agglomeration due to the compensation of the electrostatic repulsive force by the high ionic strength of phosphate buffered saline (PBS) [42]. In the present study we have carefully avoided this phenomenon by applying the suspensions to the animals and using the suspensions for chemical analyses immediately after preparation.

Extensive characterization of the particles revealed that the size of the $50 \mathrm{~nm}$ particles corresponds to the manufacturer's description. The $250 \mathrm{~nm}$ particles turn out to be significantly smaller and some are build-up from several nano-sized particles, whereas the $50 \mathrm{~nm}$ particles were monocrystalline. It turns out to be difficult to obtain gold particles with exactly the same characteristics with only the primary size as a variable. Due to differences in the production process, the $250 \mathrm{~nm}$ particles may have a different appearance and build-up compared to $50 \mathrm{~nm}$ particles as was shown by electron microscopy techniques.

\section{Conclusions}

Both single and agglomerated $50 \mathrm{~nm}$ and $250 \mathrm{~nm}$ particles generate a mild inflammatory reaction after intratracheal instillation as indicated by small increases in inflammatory cells, pro-inflammatory cytokine production or acute phase protein expression. The effects are the least for single $50 \mathrm{~nm}$ gold particles. Both agglomerated as well as single nanoparticles were taken up by macrophages.

Extensive particle characterization reveals that primary particle size, concentration of the gold suspension and particle purity are important features to check, since these characteristics may deviate from the manufacturer's description. The hypothesis was that the lung might deal differently with agglomerated and single citrate stabilized gold nanoparticles of different sizes

Table 3 Overview significant changes and trends after gold instillation

\begin{tabular}{lcccccccc}
\hline & \multicolumn{9}{c}{ Local pulmonary effects } & \multicolumn{2}{c}{ Systemic effects } \\
\hline & & \multicolumn{2}{c}{ Inflammatory cells } & \multicolumn{2}{c}{ Cytokines } & Cell damage & \multicolumn{2}{c}{ Acute phase proteins } \\
& Cells & Macrophages & Neutrophils & IL-6 & TNF- $\alpha$ & ALP & Fibrinogen & CRP \\
\hline $50 \mathrm{~nm}$ single & - & - & $\uparrow$ & - & - & - & - & $\uparrow^{*}$ \\
\hline $250 \mathrm{~nm}$ single & - & - & $\uparrow^{*}$ & $\uparrow$ & $\uparrow$ & - & $\uparrow^{*}$ & $\uparrow^{*}$ \\
\hline $50 \mathrm{~nm}$ agg & - & - & $\uparrow$ & - & $\uparrow$ & $\uparrow^{*}$ & $\uparrow^{*}$ \\
\hline $250 \mathrm{~nm}$ agg & $\uparrow$ & $\uparrow$ & - & - & - & - & - & $\uparrow^{*}$ \\
\hline quartz & $\uparrow^{*}$ & - & $\uparrow^{*}$ & - & - & $\uparrow^{*}$ & $\uparrow^{*}$ \\
\hline
\end{tabular}

* indicates a statistically significant effect $(P<0.05)$. 
after intratracheal instillation, but there seem to be no major differences. We conclude that single $50 \mathrm{~nm}$ gold particles do not pose a greater acute hazard than their agglomerates or slightly larger gold particles when using pulmonary inflammation as a marker for toxicity.

\section{Methods}

Animals

Male WU Wistar-derived rats of 8 weeks of age and around 250 grams of body weight were obtained from Harlan, The Netherlands. Animals were bred under SPF conditions and kept barrier maintained during the experiment. Conventional feed (Special Diets Services) and tap water were provided ad libitum. Husbandry conditions were maintained according to all applicable provisions of the national law: Experiments on Animals Act. The experiment was approved by an independent ethical committee prior to the study.

\section{Experimental set-up}

A single dose of $1.6 \mathrm{mg} / \mathrm{kg}$ bw in $0.5 \mathrm{ml}$ of $50 \mathrm{~nm}$ or $250 \mathrm{~nm}$ gold particles was delivered in the rat lung by intratracheal instillation under isoflurane anaesthesia. The $50 \mathrm{~nm}$ and $250 \mathrm{~nm}$ gold suspensions (BBI International, UK) were custom prepared at $2 \mathrm{mg} / \mathrm{ml}$. Solutions containing the same trace elements and reagents except for 50 and $250 \mathrm{~nm}$ gold particles (BBI International, UK) were used as a vehicle control (4.5 volumeparts control solution $50 \mathrm{~nm}$ and 4.5 parts $250 \mathrm{~nm}$ control solution and 1 part ultrapure water). Suspensions containing single $50 \mathrm{~nm}$ or $250 \mathrm{~nm}$ particles were prepared by diluting 9 volumeparts of 50 or $250 \mathrm{~nm}$ particles with 1 volumepart sterilized ultrapure water. Agglomerated (agg) suspensions were prepared by diluting 9 volume parts of particles with 1 volumepart sterilized $10 \times$ PBS. A single dose of $1.6 \mathrm{mg} / \mathrm{kg}$ bw quartz (DQ12, crystalline silica) in ultrapure water was used as a positive control. All solutions were sonicated for 30 seconds in an ultrasonic water bath prior to administration to the animals. Animals were sacrificed at 3 hours or 24 hours after administration of the particles, and bronchoalveolar lavage fluid (BALF) and blood were collected. Treatment groups for gold consisted of 6 animals and for quartz of 3 animals.

\section{Characterization of gold particles and quartz}

Gold particles of $50 \mathrm{~nm}$ and $250 \mathrm{~nm}$ particles were purchased in sterile bottles and contained besides colloidal gold with a citrate shell, trace elements of substances used during synthesis. Endotoxin levels of the gold solutions of 50 and $250 \mathrm{~nm}$ were determined in a LAL assay and there were no detectable levels. The $\mathrm{pH}$ of the 50 and $250 \mathrm{~nm}$ solutions and control solutions were measured using indicator strips in the range of $\mathrm{pH} 1-10$ and
6.4-8.0 (Merck). The zetapotential (Zetasizer, Malvern Instruments, UK) was determined in a triplicate measurement of a $20 \mu \mathrm{g} / \mathrm{ml}$ sample as a $10 \%$ dilution with ultrapure water or $10 \times$ PBS. The samples were first diluted with either ultrapure water or $10 \times$ PBS and then further diluted to the desired concentration using ultrapure water. Prior to preparing the quartz solutions, DQ12 was baked at $220^{\circ} \mathrm{C}$ for $3 \mathrm{hrs}$ to inactivate possible endotoxin on the particle surface.

The concentration of gold in the commercial available solutions was determined by Inductively Coupled Plasma-Mass Spectrometry (ICP-MS) by MiPlaza Materials Analysis, Philips, Eindhoven, the Netherlands. Three independent samples were digested with aqua regia in a heating block system. The size distribution of the $50 \mathrm{~nm}$ and $250 \mathrm{~nm}$ gold particles directly after preparing the suspensions for intratracheal instillation were determined in 6 separate measurements using tracking analysis of Brownian motion with a laser illuminated microscopical technique (LM20, NanoSight Ltd, UK). The size of the $250 \mathrm{~nm}$ agglomerates were in the maximal range of the measurement technique resulting in three representative measurements.

\section{Transmission electron microscopy (TEM) analysis}

A Tecnai 20F electron microscope equipped with a fieldemission gun operated at $200 \mathrm{kV}$ was employed to investigate the structure and the chemical composition of the gold particles with diameters of 50 and $250 \mathrm{~nm}$. Samples were prepared by putting a drop of the suspension of the gold particles on a holey carbon film applied on a copper grid placed on filter paper. The gold particles were present well dispersed on the carbon film. Images were taken using conventional transmission electron microscopy (TEM) and scanning transmission electron microscopy (STEM) with a high-angle annular dark-field (HAADF) [43] and a secondary electron detector. STEM enabled us to execute elemental analysis by energy-dispersive X-ray (EDX) analysis at predefined spots. To assess the crystallographic structure of the gold particles, selected area electron diffraction and lattice imaging were performed.

TEM analysis of particles in lung cells in the BALF was performed by pooling cells per exposure group and by fixation in $2 \%$ glutaraldehyde in cacodylatebuffer $(\mathrm{pH}$ 7.2-7.2), supplemented with $0.025 \mathrm{mM} \mathrm{CaCl}_{2}$ and 0.05 $\mathrm{mM} \mathrm{MgCl} 2$. The cells were embedded in gelatin, which was allowed to solidify to obtain "cell-tissue-blocks". The blocks were fixed in 4\% paraformaldehyde (PFA), and postfixed with osmium tetroxide $(\mathrm{OsO} 4)$ and potassium ferrocyanide $(\mathrm{KFeCN})$, dehydrated with the use of ethanol and embedded in Epon. Ultrathin sections were made, post stained with lead citrate and uranylacetate and examined in a FEI Tecnai 12 . Of the $24 \mathrm{hr}$ groups at least three sections out of 12 sections were analyzed. 


\section{Biological effect markers}

At 3 and 24 hours after intratracheal administration, rats were anesthetized via i.p. injection with a mixture of Ketamine/Rompun and sacrificed by exsanguination via the abdominal aorta. The lungs were perfused with saline to remove all the blood in the tissue. After ligation of the left bronchus, the right lung was lavaged (three in-and-out lavages with the same fluid) with a volume of saline corresponding to $27 \mathrm{ml} / \mathrm{kg}$ of body weight at $37^{\circ}$ to obtain BALF.

BALF was analyzed for the following parameters: total cell number (Coulter counter), differential cell count of 400 cells (cytospins), monocyte chemotactic protein -1 (MCP-1, Invitrogen), tumor necrosis factor $\alpha$ (TNF- $\alpha$, Arcus Biologicals and eBiosciences), interleukin-6 (IL-6, Demeditec Diagnostics and eBiosciences) and macrophage inflammatory protein -2 (MIP-2, Arcus Biologicals). LDH, ALP, albumin and total protein were measured using an autoanalyser (LX20-Pro, BeckmanCoulter, Woerden, the Netherlands) using kits from the same manufacturer.

EDTA blood was used to determine the total number of cells and differential cell count. In citrate plasma, protein levels of van Willebrand factor (vWF, American Diagnostica), fibrinogen (Genway) and C-reactive protein (CRP, Helica Biosystems) were determined.

\section{Statistics}

Data were analyzed by analysis of variance (ANOVA single factor) and where appropriate by a Bonferroni post-hoc analysis (Graphpad Prism). Differential cell count data are not normally distributed; therefore, the Kruskal-Wallis nonparametric test was used. Statistical significance is indicated with a * (P value $<0.05)$. In all graphs, error bars represent the standard deviation of the mean.

\section{Additional material}

Additional file 1: Figure S1: Light microscopic images of particulate material in macrophages. A) No particulate material is found inside macrophages from BALF in animals receiving the vehicle control. B and C) Animals received $50 \mathrm{~nm}$ gold particles. Black particulate material is seen in the cytoplasm (blue) and not in the nucleus (purple) of macrophages. D) Black particulate material is observed in macrophages of animals that received $250 \mathrm{~nm}$ gold particles. Bars represent $12 \mu \mathrm{m}$.

\section{Acknowledgements}

We would like to thank J. Quik from the RIVM, Bilthoven, the Netherlands for valuable assistance on zetapotential measurements, P. Krystek from MiPlaza Materials Analysis, Philips, Eindhoven, the Netherlands for gold concentration measurements, K. Vocking for excellent assistance with the cellular electronmicroscpy, D.P.K Lankveld for relevant input on the study design, D. L.A.C. Leseman, R.F. Vlug, J.C. Strootman, P.K. Beekhof and A.J.F Boere for excellent technical assistance and R. Schins for providing the DQ12 quartz.

\begin{abstract}
Author details
${ }^{1}$ Centre for Environmental Health Research, National Institute for Public Health and the Environment, Bilthoven, the Netherlands. ${ }^{2}$ Biomolecular Imaging, Faculty of Science, University of Utrecht, the Netherlands. ${ }^{3}$ Laboratory for Health Protection Research, National Institute for Public Health and the Environment, Bilthoven, the Netherlands.
\end{abstract}

\section{Authors' contributions}

IG designed the study. IG, JAP, LJJF and JWG carried out the study. IG collected, analyzed, interpreted data and drafted the manuscript. JAP, JWG, and EHJMJ generated and interpreted data. WHdeJ and FRC contributed to the study design and writing of the manuscript. All authors read and approved the final manuscript.

\section{Competing interests}

The authors declare that they have no competing interests.

Received: 23 June 2010 Accepted: 2 December 2010

Published: 2 December 2010

\section{References}

1. Stoeger T, Reinhard C, Takenaka S, Schroeppel A, Karg E, Ritter B, Heyder J, Schulz H: Instillation of six different ultrafine carbon particles indicates a surface area threshold dose for acute lung inflammation in mice. Environ Health Perspect 2006, 114:328-333.

2. Duffin R, Tran L, Brown D, Stone V, Donaldson K: Proinflammogenic effects of low-toxicity and metal nanoparticles in vivo and in vitro: highlighting the role of particle surface area and surface reactivity. Inhal Toxicol 2007. 19:849-56.

3. Dick CA, Brown DM, Donaldson $\mathrm{K}$, Stone V: The role of free radicals in the toxic and inflammatory effects of four different ultrafine particle types. Inhal Toxicol 2003, 15:39-52.

4. Brown DM, Wilson MR, MacNee W, Stone V, Donaldson K: Size-dependent proinflammatory effects of ultrafine polystyrene particles: a role for surface area and oxidative stress in the enhanced activity of ultrafines. Toxicol Appl Pharmacol 2001, 175:191-199.

5. Oberdorster G, Oberdorster E, Oberdorster J: Nanotoxicology: an emerging discipline evolving from studies of ultrafine particles. Environ Health Perspect 2005, 113:823-839.

6. Kreyling WG, Semmler M, Moller W: Dosimetry and toxicology of ultrafine particles. J Aerosol Med 2004, 17:140-152.

7. Warheit $D B$, Reed $K L$, Sayes $C M$ : A role for nanoparticle surface reactivity in facilitating pulmonary toxicity and development of a base set of hazard assays as a component of nanoparticle risk management. Inhal Toxicol 2009, 21(Suppl 1):61-67.

8. Dhawan A, Sharma V, Parmar D: Nanomaterials: A challenge for toxicologists. Nanotoxicology 2008, 3:1-9.

9. Balbus JM, Maynard AD, Colvin VL, Castranova V, Daston GP, Denison RA, Dreher KL, Goering PL, Goldberg AM, Kulinowski KM, Monteiro Riviere NA, Oberdorster G, Omenn GS, Pinkerton KE, Ramos KS, Rest KM, Sass JB, Silbergeld EK, Wong BA: Meeting report: hazard assessment for nanoparticles-report from an interdisciplinary workshop. Environ Health Perspect 2007, 115:1654-9.

10. Park MV, Annema W, Salvati A, Lesniak A, Elsaesser A, Barnes C, McKerr G, Howard CV, Lynch I, Dawson KA, Piersma AH, de Jong WH: In vitro developmental toxicity test detects inhibition of stem cell differentiation by silica nanoparticles. Toxicol Appl Pharmacol 2009, 240:108-116.

11. Murdock RC, Braydich-Stolle L, Schrand AM, Schlager JJ, Hussain SM Characterization of Nanomaterial Dispersion in Solution Prior to In Vitro Exposure Using Dynamic Light Scattering Technique. Toxicol Sci 2007, 101:239-253.

12. SCENIHR: Risk assessment of products of nanotechnologies. 2009 [http://ec.europa.eu/health/ph_risk/committees/04_scenihr/docs/ scenihr_o_023.pdf].

13. Oberdorster G, Sharp Z, Atudorei V, Elder A, Gelein R, Lunts A, Kreyling W, Cox C: Extrapulmonary translocation of ultrafine carbon particles following whole-body inhalation exposure of rats. J Toxicol Environ Health A 2002, 65:1531-1543.

14. Kreyling WG, Semmler M, Erbe F, Mayer P, Takenaka S, Schulz H Oberdorster G, Ziesenis A: Translocation of ultrafine insoluble iridium 
particles from lung epithelium to extrapulmonary organs is size dependent but very low. J Toxicol Environ Health A 2002, 65:1513-1530.

15. Geiser M, Casaulta M, Kupferschmid B, Schulz H, Semmler-Behnke M, Kreyling $W$ : The role of macrophages in the clearance of inhaled ultrafine titanium dioxide particles. Am J Respir Cell Mol Biol 2008, 38:371-376.

16. Pernodet N, Fang X, Sun Y, Bakhtina A, Ramakrishnan A, Sokolov J, Ulman A, Rafailovich M: Adverse effects of citrate/gold nanoparticles on human dermal fibroblasts. Small 2006, 2:766-773.

17. Shukla R, Bansal V, Chaudhary M, Basu A, Bhonde RR, Sastry M: Biocompatibility of gold nanoparticles and their endocytotic fate inside the cellular compartment: a microscopic overview. Langmuir 2005, 21:10644-10654.

18. Pan Y, Neuss S, Leifert A, Fischler M, Wen F, Simon U, Schmid G, Brandau W, Jahnen Dechent W: Size-dependent cytotoxicity of gold nanoparticles. Small 2007, 3:1941-9.

19. Goodman CM, McCusker CD, Yilmaz T, Rotello VM: Toxicity of gold nanoparticles functionalized with cationic and anionic side chains. Bioconjug Chem 2004, 15:897-900.

20. Yu L, Yung L, Ong C, Tan Y, Balasubramaniam K, Hartono D, Shui G, Wenk M, Ong W: Translocation and effects of gold nanoparticles after inhalation exposure in rats. Nanotoxicology 2007, 1:235-242.

21. Takenaka S, Karg E, Kreyling WG, Lentner B, Moller W, Behnke-Semmler M, Jennen L, Walch A, Michalke B, Schramel P, Heyder J, Schulz H: Distribution pattern of inhaled ultrafine gold particles in the rat lung. Inhal Toxicol 2006, 18:733-740.

22. de Jong WH, Hagens WI, Krystek P, Burger MC, Sips AJ, Geertsma RE: Particle size-dependent organ distribution of gold nanoparticles after intravenous administration. Biomaterials 2008, 29:1912-9.

23. Semmler-Behnke M, Kreyling WG, Lipka J, Fertsch S, Wenk A, Takenaka S, Schmid G, Brandau W: Biodistribution of 1.4- and 18-nm gold particles in rats. Small 2008, 4:2108-11.

24. Sadauskas E, Jacobsen NR, Danscher $G$, Stoltenberg M, Vogel U, Larsen A, Kreyling W, Wallin H: Biodistribution of gold nanoparticles in mouse lung following intratracheal instillation. Chem Cent J 2009, 3:16.

25. Henderson RF, Driscoll KE, Harkema JR, Lindenschmidt RC, Chang IY, Maples KR, Barr EB: A comparison of the inflammatory response of the lung to inhaled versus instilled particles in F344 rats. Fundam Appl Toxicol 1995, 24:183-197.

26. Donaldson K, Faux S, Borm PJA, Stone V: Approaches to the toxicological testing of particles. In Particle Toxicology. Volume 1. Edited by: Donaldson K, Borm PJA. Taylor and Francis group; 2007:299-316.

27. 27.Duffin R, Gilmour PS, Schins RP, Clouter A, Guy K, Brown DM, MacNee W, Borm PJ, Donaldson K, Stone V: Aluminium lactate treatment of DQ12 quartz inhibits its ability to cause inflammation, chemokine expression and nuclear factor-kappaB activation. Toxicol Appl Pharmacol 2001, 176:10-17.

28. Cobben NA, Jacobs JA, Dieijen-Visser MP, Mulder PG, Wouters EF, Drent M: Diagnostic value of BAL fluid cellular profile and enzymes in infectious pulmonary disorders. Eur Respir J 1999, 14:496-502.

29. Tabata Y, Ikada Y: Effect of the size and surface charge of polymer microspheres on their phagocytosis by macrophage. Biomaterials 1988, 9:356-362.

30. Gonzalez O, Smith RL, Goodman SB: Effect of size, concentration, surface area, and volume of polymethylmethacrylate particles on human macrophages in vitro. J Biomed Mater Res 1996, 30:463-473.

31. Geiser M: Morphological aspects of particle uptake by lung phagocytes. Microsc Res Tech 2002, 57:512-522.

32. Seiler F, Rehn B, Rehn S, Hermann M, Bruch J: Quartz exposure of the rat lung leads to a linear dose response in inflammation but not in oxidative DNA damage and mutagenicity. Am J Respir Cell Mol Biol 2001, 24:492-498.

33. Driscoll KE, Carter JM, Howard BW, Hassenbein D, Burdick M, Kunkel SL, Strieter RM: Interleukin-10 regulates quartz-induced pulmonary inflammation in rats. Am J Physiol 1998, 275:L887-L894.

34. Albrecht C, Schins RP, Hohr D, Becker A, Shi T, Knaapen AM, Borm PJ: Inflammatory time course after quartz instillation: role of tumor necrosis factor-alpha and particle surface. Am J Respir Cell Mol Biol 2004, 31:292-301.

35. Doherty TM: T-cell regulation of macrophage function. Curr Opin Immunol 1995, 7:400-404
36. Nel A, Xia T, Madler L, Li N: Toxic potential of materials at the nanolevel. Science 2006, 311:622-627.

37. Auffan M, Rose J, Bottero JY, Lowry GV, Jolivet JP, Wiesner MR: Towards a definition of inorganic nanoparticles from an environmental, health and safety perspective. Nat Nanotechnol 2009, 4:634-641.

38. Haruta M: When gold is not noble: catalysis by nanoparticles. Chem Rec 2003, 3:75-87.

39. Sau TK, Pal A, Pal T: Size Regime Dependent Catalysis by Gold Nanoparticles for the Reduction of Eosin. The Journal of Physical Chemistry B 2001, 105:9266-9272

40. Sharma VK: Aggregation and toxicity of titanium dioxide nanoparticles in aquatic environment-a review. J Environ Sci Health A Tox Hazard Subst Environ Eng 2009, 44:1485-1495.

41. Zhou J, Ralston J, Sedev R, Beattie DA: Functionalized gold nanoparticles: synthesis, structure and colloid stability. J Colloid Interface Sci 2009, 331:251-262.

42. Sakura T, Takahashi T, Kataoka K, Nagasaki Y: One-pot preparation of mono-dispersed and physiologically stabilized gold colloid. Colloid Polym Sci 2005, 284:97-101.

43. Williams DB, Carter CB: Basics of symmetry determination. Transmission Electron Microscopy III Imaging Plenum Press New York; 1996, 359.

doi:10.1186/1743-8977-7-37

Cite this article as: Gosens et al:: Impact of agglomeration state of nano- and submicron sized gold particles on pulmonary inflammation. Particle and Fibre Toxicology 2010 7:37.

\section{Submit your next manuscript to BioMed Central and take full advantage of:}

- Convenient online submission

- Thorough peer review

- No space constraints or color figure charges

- Immediate publication on acceptance

- Inclusion in PubMed, CAS, Scopus and Google Scholar

- Research which is freely available for redistribution

Submit your manuscript at www.biomedcentral.com/submit
Ciomed Central 